$1 \mathrm{P} 212$

\section{界面通過法で作製したジャイアントリポソームのラメラリ ティーの定量的解析}

Measuring the lamellarity of giant liposomes prepared by inverted emulsion method

Masataka Chiba ${ }^{1}$, Makito Miyazaki ${ }^{1}$, Shin'ichi Ishiwata ${ }^{1,2}$ ( ${ }^{1}$ Dept. of Physics, Waseda Univ., ${ }^{2}$ WABIOS, Waseda Univ.)

The inverted emulsion method of liposome formation is pushing water-inoil droplets through the water/oil interface. This method is efficient for encapsulating proteins and is thus widely used for modeling cells. However, the lamellarity of liposomes prepared by this method has not been evaluated quantitatively (e.g., dependency on lipid composition). Here we prepared fluorescently labeled liposomes and analyzed the fluorescence intensity of the membrane of individual liposomes under the microscope. By comparing the intensities of the membrane before and after quenching of the fluorescent dye on the outermost monolayer and monitoring the permeability of the inner and the outer buffers in the presence of hemolysin, we concluded that $>90 \%$ of liposomes were unilamellar.
$1 \mathrm{P} 215$

\section{低い pH が誘起する DOPS/MO 膜の液晶相からキュービック 相への相転移の初期過程}

Initial Step of Low pH-Induced Lamellar to Bicontinuous Cubic Phase Transition in Dioleoylphosphatidylserine/Monoolein

Toshihiko Oka ${ }^{1,2}$, Taka-aki Tsuboi ${ }^{1}$, Masahito Yamazaki ${ }^{1,2}\left({ }^{1}\right.$ Grad. Sch. Sci, Shizuoka Univ., ${ }^{2}$ Res. Inst. of Electronics, Shizuoka Univ.)

We investigated the initial step of low $\mathrm{pH}$-induced $\mathrm{L}_{\alpha}$ to $\mathrm{Q}_{\mathrm{II}}^{\mathrm{D}}$ phase transition in mixed lipid membrane of dioleoylphosphatidylserine(DOPS)/ monoolein using small angle X-ray scattering with a stopped flow apparatus. We observed that the $\mathrm{L}_{\alpha}$ phase of MLV converted into the $\mathrm{H}_{\mathrm{II}}$ phase, and then the $\mathrm{H}_{\mathrm{II}}$ phase converted into the $\mathrm{Q}_{\mathrm{II}}^{\mathrm{D}}$ phase. The rate constant of the initial step depended on final $\mathrm{pH}$ and DOPS concentrations. We also found the difference in the $\mathrm{L}_{\alpha}-\mathrm{H}_{\mathrm{II}}$ transition between non-filtered MLV and filtered one through $1 \mu \mathrm{m}$ pores. The results indicate $\mathrm{L}_{\alpha}$ phase of large MLV converted into $\mathrm{H}_{\mathrm{II}}$ phase fast, while that of small MLV did slow. The rate of the small MLV might be controlled by the size growth of lipid particles.

\section{$1 \mathrm{P} 213$}

\section{細胞毒性を有する酸化コレステロールのホスファチジルコリ ンニ分子層膜内存在位置}

Locations of cytotoxic oxysterols in phosphatidylcholine bilayer membranes

Tatsuya Hoshino ${ }^{1}$, Takaaki Hikima ${ }^{2}$, Masaki Takata ${ }^{2}$, Toshihide Kobayashi ${ }^{3}$, Hiroshi Takahashi ${ }^{1}$ ( ${ }^{1}$ Grad. Sch. Sci \& Tech., Gunma Univ., ${ }^{2}$ Harima Inst., Riken, ${ }^{3}$ Wako Inst., Riken)

Some types of oxysterols are cytotoxic. For example, 7 $\beta$ hydroxycholesterol $(7 \beta-\mathrm{OH})$ and 25-hydroxycholesterol $(25-\mathrm{OH})$ have been reported to be associated with neurodegenerative diseases. In this study, we have explored the locations of these oxysterols in in phosphatidylcholine (POPC) bilayers. It was found that $25-\mathrm{OH}$ is located more near the center of the POPC bilayers in comparison with normal cholesterol. On the other hand, $7 \beta-\mathrm{OH}$ is located more near the polar POPC headgroup regions. We estimated these locations from the combination of the X-ray diffraction data and the molecular volume data obtained by the $\mathrm{D}_{2} \mathrm{O} / \mathrm{H}_{2} \mathrm{O}$ flotation method. We will compare these results with those of a recent MD simulation study (JACS, 131 (2009) 4854).

\section{$1 \mathrm{P} 214$}

\section{合成セラミド 2 の相挙動及びコレステロールとの相互作用 \\ Phase Behavior of Synthetic Ceramide2((2S,3R)-2- \\ Octadecanoylaminooctadecane-1,3-diol) and Its Interaction with Cholesterol}

Kenta Takada ${ }^{1}$, Yasuko Obata ${ }^{2}$, Nobutaka Shimizu ${ }^{3}$, Hiroshi Takahashi ${ }^{1}$ ( ${ }^{1}$ Grad.Sch.Eng., Gunma Univ., ${ }^{2}$ Hoshi Univ., ${ }^{3} \mathrm{KEK}-\mathrm{PF}$ )

Stratum corneum plays an important role in the barrier and moisture retention function of the skin. The synthetic ceramide2 (Cer2) has a similar chemical structure to ceramide 2 that is the main ceramide component of stratum corneum. In this study, to elucidate the role of ceramide in the stratum corneum, we investigated the structural changes and phase behavior of Cer2. We found that Cer2 converts to a stable phase from a metastable phase by incubating just below of melting temperature of Cer2. Such stable phase of Cer2 has not been taken into consideration in previous studies on Cer2 system. Thermal behavior of Cer $2 /$ cholesterol now is under investigation, paying attention to the existence of stable phase of Cer2.

\section{抗菌ペプチド・マガイニン 2 が誘起するポア形成に対する脂 質膜のカ学特性の効果}

Effects of Mechanical Properties of Lipid Membranes on

Antimicrobial Peptide Magainin 2-Induced Pore Formation

M. A. Sayem Karal ${ }^{1}$, Taka-aki Tsuboi ${ }^{2}$, Md. Jahangir Alam ${ }^{3}$, Md. Zahidul Islam ${ }^{1}$, Masahito Yamazaki ${ }^{1,2,3}\left({ }^{1} \mathrm{Grad}\right.$. Sch. Sci. \& Tech., Shizuoka Univ., ${ }^{2}$ Grad. Sch. Sci., Shizuoka Univ., ${ }^{3}$ Res. Inst. Electronics, Shizuoka Univ.)

Antimicrobial peptide magainin 2(mag) forms pores in biomembranes to induce leakage in cells, which is a main cause of its bactericidal activity. Here we investigated the effect of mechanical properties of lipid membranes on the rate constant $\left(k_{\mathrm{p}}\right)$ of mag-induced pore formation using the single GUV method. Lower tension induced pore formation in 40\%diC 12:0-phosphatidylglycerol(DLPG)/60\%diC13:0-

phosphatidylcholine(DTPC) than in $40 \% \mathrm{DOPG} / 60 \% \mathrm{DOPC}$ membranes. On the other hand, $k_{\mathrm{p}}$ values in $40 \% \mathrm{DLPG} / 60 \% \mathrm{DTPC}-\mathrm{GUVs}$ were much larger than those of $40 \%$ DOPG $/ 60 \%$ DOPC-GUVs (e.g., $4.8 \times 10^{-2}$ and $1.6 \times 10^{-2} \mathrm{~s}^{-1}$ for $30 \mu \mathrm{M} \mathrm{mag}$, respectively). In contrast, presence of high concentration of cholesterol inhibited the mag-induced pore formation. We discuss the mechanism of these results.

$1 \mathrm{P} 217$

\section{張カによる脂質膜のポア形成の速度定数に対する静電相互作 用の効果}

Effects of Electrostatic Interactions on Rate Constants of Tension-Induced Pore Formation in Single GUVs

Taka-aki Tsuboi ${ }^{1}$, M. A. Sayem $\mathrm{Karal}^{2}$, Victor Levadny ${ }^{2,3}$, Masahito Yamazaki ${ }^{1,2,4}$ ( ${ }^{1}$ Grad. Sch. Sci., Shizuoka Univ., ${ }^{2}$ Grad. Sch. Sci. \& Tech., Shizuoka Univ. ${ }^{3}$ Rus. Acad. Sci., ${ }^{4}$ Res. Inst. Electronics, Shizuoka Univ.)

When external forces are applied to cells, tension is induced in biomembranes. We investigated the rate constant $\left(k_{\mathrm{p}}\right)$ of tension-induced pore formation in lipid membranes of GUVs, which were analyzed using the mean first passage time [1]. Here we investigated effects of the electrostatic interactions. $k_{\mathrm{p}}$ values of $40 \%$ dioleoylphosphatidylglycerol (DOPG)/60\%dioleoylphosphatidylcholine(DOPC)-GUVs were larger than those of DOPC-GUVs (e.g., $1.9 \times 10^{-2}$ and $2.9 \times 10^{-3} \mathrm{~s}^{-1}$ at tension 7.0 $\mathrm{mN} / \mathrm{m})$. The decrease in salt concentration increased $k_{\mathrm{p}}$ values of $40 \%$ DOPG $/ 60 \%$ DOPC-GUVs (e.g., at $5.0 \mathrm{mN} / \mathrm{m}, 1.9 \times 10^{-2}$ and $1.7 \times 10^{-3}$ $\mathrm{s}^{-1}$ in $0 \mathrm{mM}$ and $150 \mathrm{mM} \mathrm{NaCl}$ ). These data indicate that $k_{\mathrm{p}}$ increases as the electrostatic interactions increase.

[1] Langmuir, 29, 3848, 2013 